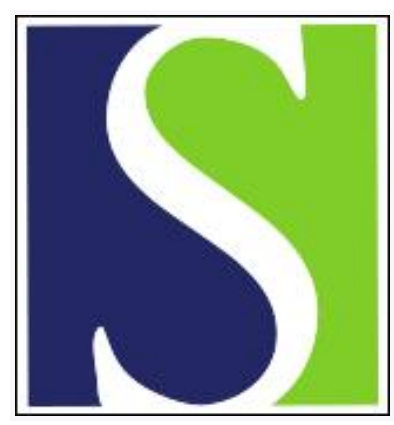

Scand J Work Environ Health 1992;18(2):97-100

https://doi.org/10.5271/sjweh.1595

Issue date: 01 Apr 1992

\title{
Does long-term concrete work cause silicosis?
}

by Tornling G, Tollqvist J, Askergren A, Hallin N, Hogstedt C

Affiliation: Department of Thoracic Medicine, Karolinska Hospital, Stockholm, Sweden.

This article in PubMed: www.ncbi.nlm.nih.gov/pubmed/1604279

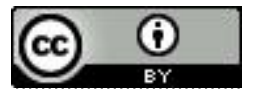




\title{
Does long-term concrete work cause silicosis?
}

\author{
by Göran Tornling, MD, ${ }^{1}$ Jan Tollqvist, MD, ${ }^{2}$ Alf Askergren, MD, ${ }^{2}$ Nils Hallin, MSc, ${ }^{2}$ \\ Christer Hogstedt, $\mathrm{MD}^{3,4}$
}

\begin{abstract}
TORNLING G, TOLLQVIST J, ASKERGREN A, HALLIN N, HOGSTEDT C. Does long-term concrete work cause silicosis? Scand J Work Environ Health 1992;18:97-100. The machining of cast concrete often produces heavy exposure to respirable silica dust. Work with concrete in general results in considerably less exposure, however, and only a few cases of silicosis due to work with concrete have been reported. Telephone interviews with detailed questions on occupational history were made with 271 construction workers specializing in concrete work for more than 20 years, and exposure data were evaluated for different work tasks. The mean cumulative exposure of subjects to silica was estimated to be $2.4 \mathrm{mg} \cdot$ years $\cdot \mathrm{m}^{-3}$. Chest radiographs were classified according to the International Labour Office classification. There was no suspicion of silicosis for any of the workers. The risk of contracting silicosis from work with concrete in the Swedish construction industry in recent decades is considered to be slight and does not justify general, periodic chest radiographic screening.
\end{abstract}

Key terms: chest radiograph, concrete, construction work, silica, silicosis.

Investigations by Bygghälsan, the Swedish Construction Industry's Organization for Working Environment Safety and Health, have shown that concrete workers might have substantial exposure to silica dust. Operations that cause such exposure are the grinding, cutting, and drilling of cast concrete. Time-weighted exposure levels estimated by Bygghälsan have, on occasion, been at or above the Swedish occupational exposure limit of $0.1 \mathrm{mg} \cdot \mathrm{m}^{-3}$ respirable silica dust.

A criteria document from the National Institute for Occupational Safety and Health (NIOSH) in the United States (1) cites studies showing that exposure at a time-weighted mean value of 6.8 million particles per cubic foot (mppcf), measured by the impinger method, of silica in the mining industry caused silicosis in $3.4 \%$ of the miners and also that cases of silicosis have occurred in the ceramics industry, where the exposure level has been $4-5 \mathrm{mppcf}$ for more than 10 years. Ten million particles per cubic foot of granite dust equals around $0.1 \mathrm{mg} \cdot \mathrm{m}^{-3}$ of respirable silica dust (2). However, this transformation factor is not necessarily accurate when applied to dust levels at a construction site, where the density and size distribution of the particles is uneven. Exposure levels for Swedish construction workers have probably been lower than those in the investigations cited in the NIOSH document, but of the same magnitude.

I Department of Thoracic Medicine, Karolinska Hospital, Stockholm, Sweden.

2 The Swedish Construction Industry's Organization for Working Environment Safety and Health (Bygghälsan), Stockholm, Sweden.

${ }^{3}$ Department of Occupational Medicine, Karolinska Hospital, Stockholm, Sweden.

${ }^{4}$ National Institute of Occupational Health, Solna, Sweden.

Reprint requests to: Dr G Tornling, Department of Thoracic Medicine, Karolinska Hospital, S-104 01 Stockholm, Sweden.
In the international literature only a few cases of silicosis due to concrete work have been reported (3-8). The association between concrete work and radiological silicosis has not been previously studied with epidemiologic methods. In a study of chest radiographic examinations within Bygghälsan in the early 1970s, Askergren \& Tollqvist (9) found no case of silicosis among 269 construction workers with "untraditional" silica exposure, including concrete work, but only $20 \%$ of those examined had worked more than 20 years as a construction worker.

This study was designed to investigate the possibility of radiological signs of silicosis among Swedish construction workers who have specialized in concrete work for more than 20 years and to evaluate the suitability of periodic chest radiographs in a health control program for concrete workers. Furthermore, by calculating individual cumulative exposure, the investigation contributes to the risk evaluation of exposure to quartz levels lower than those earlier associated with silicosis.

\section{Subjects and methods}

The study base for this investigation consisted of those construction workers in the Stockholm region who, since the early 1970 s, had attended one or more health examinations at the Bygghälsan. Among the approximately 60000 records there were 2056 concrete workers who were 50 years or older. According to their medical records, 483 of them had worked 30 years or more with concrete with less than two years in other work with silica exposure. One hundred and twentysix lived outside the Stockholm region or were unable or unwilling to take part in the investigation. An experienced occupational health nurse performed a stan- 
dardized telephone interview with detailed questions on month-by-month occupational history with the remaining 357 individuals. Three hundred and twentynine of the men had worked 20 years or more as concrete workers and not more than five years in other occupations involving silica exposure; these men were chosen for inclusion in the study.

Most of the workers had previous chest radiographs less than 10 years old, and those who did not were referred for a new examination. Five individuals who lived outside the Stockholm area were not referred for radiographic investigation, and for 27 the films were unavailable at the time of the study. Twenty-six individuals were unwilling to undergo a radiographic investigation, mainly due to age or nonpulmonary diseases. The final study group thus consisted of 271 concrete workers. They were born in 1906-1935, their mean age was 63 (SD 6) years, their average time in concrete work was 34 (SD 5) years, and the average time from first exposure to the chest radiograph used in this study was 37 (SD 7) years. Ninety percent had less than two years of exposure to silica dust from sources other than concrete, and all had less than five years of such exposure. Fifty-two $(19 \%)$ had never smoked, $126(46 \%)$ were ex-smokers, and $93(34 \%)$ were current smokers.

Exposure levels for the various tasks comprising concrete work were estimated from earlier investigations by Bygghälsan and other investigators (table 1). Swedish concrete contains gravel or crushed rock with a high content of silica. The concrete is usually produced in concrete plants and conveyed to the building site where it is cast in molds. During the casting process no silica dust is released, and it is only when the cured concrete is machined that exposure occurs. Reinforcement produces no silica dust. Casting and plaster work is done with wet concrete, and silica exposure is minimal. Assembling precast concrete units and work with lightweight concrete usually produce dust levels below the occupational exposure limit. Cleaning and transport work produce varying exposure levels that might

Table 1. Quartz exposure and proportion of worktime spent in different work tasks. The exposure was estimated from earlier studies at Bygghälsan. The proportion of time is the average derived from the telephone interviews with the 271 concrete workers.

\begin{tabular}{lcc}
\hline Task & $\begin{array}{c}\text { Exposure } \\
\text { level } \\
\left(\mathrm{mg} \cdot \mathrm{m}^{-3}\right)\end{array}$ & $\begin{array}{c}\text { Worktime } \\
(\%)\end{array}$ \\
\hline Reinforcement & 0 & 16 \\
$\begin{array}{l}\text { Casting and plaster work } \\
\text { Unit assembly and work with }\end{array}$ & 0 & 29 \\
lightweight concrete & 0.01 & 6 \\
Cleaning and transport work & 0.01 & 14 \\
$\begin{array}{l}\text { Excavation, foundation work, } \\
\text { pipe laying }\end{array}$ & 0.01 & 7 \\
Demolition and repair work & 0.1 & 9 \\
Cutting, drilling, grinding, etc & 0.3 & 19 \\
\hline
\end{tabular}

approach the limit. Excavation, pipe laying, and foundation work might entail drilling, blasting, and the placing of gravel in pipe trenches. Dust levels might, for short periods, exceed the limit. Demolition and repair work might, in certain situations, produce very high exposure levels, and the average exposure might be above the limit value for an 8-h day. Cutting, grinding, and drilling produce large amounts of silica dust, and numerous measurements show dust levels 5-10 times the occupational exposure limit, but these tasks are usually of short duration. Concrete workers might also have laid "floating floors" by spreading and leveling sand with a very high content of silica. Earlier, the hand mixing of concrete at the worksite was also included in concrete work, and this process entailed exposure to silica-containing sand. However, these tasks were not mentioned by the concrete workers during their interviews. The time each individual had spent in various concrete work tasks was estimated from the interviews, and the individual cumulative silica exposures were calculated from the estimated exposure levels for each task.

Chest radiographs (posterior-anterior view only) were read independently and were classified according to the recommendation of the International Labour Office (ILO) (10) by three investigators who were trained in this method. For the evaluation of the sensitivity of the readings, 27 films of patients with silicosis of various stages were included. In 18 cases out of 298 the readers differed one stage or more in the classification. Ten of these were cases of known silicosis and eight involved concrete workers. New consensus readings were used in these cases. In the other cases the median reading was used, that is, the middle of the three readings was used. If two of the readings agreed they were by definition the median. Pleural changes (plaques or diffuse thickening) were considered to exist if two of the readers made a note of them.

\section{Results}

The estimated percentage of time spent in the various tasks connected with concrete work is shown in table 1. The cumulative silica exposure (average exposure in milligrams per cubic meter multiplied by exposure time in years) was calculated to a mean of 2.4 $\mathrm{mg} \cdot$ years $\cdot \mathrm{m}^{-3}(\mathrm{SD}=0.9)$ and varied between 0.2 and $5.0 \mathrm{mg} \cdot$ years $\cdot \mathrm{m}^{-3}$.

The 27 chest radiographs from known silicotics were all classified as $1 / 0$ or higher. Among the concrete workers there were 22 cases of small opacities, three of stage $1 / 0$, and one of stage $1 / 1$ (table 2). Two of these persons had rounded opacities, but the opacities were situated in the lower lung fields and thus not typical of silicosis. Those four concrete workers with stage $1 / 0$ or more were all smokers or ex-smokers, and small opacities of stage $0 / 1$ or higher were more prevalent among those who were smokers or ex-smokers (table 
3). There was no association between the presence of small opacities and age, length of exposure, cumulative silica exposure, latency, or silica exposure other than concrete dust. Pleural thickening (plaques or diffuse thickening) was observed in 64 individuals (24\%).

\section{Discussion}

The average cumulative silica dust exposure was estimated to be $2.4 \mathrm{mg} \cdot$ years $\cdot \mathrm{m}^{-3}$, an exposure level that, theoretically, may cause silicosis. However, the estimated exposure levels were somewhat uncertain due to a lack of adequate measurements. The large variations in cumulative exposure were mainly due to the workers having spent different proportions of their worktime in the various tasks. No concrete workers with radiographic findings suggestive of silicosis were found. However, four had small opacities of grade 1/0 or $1 / 1$. In two of these persons the opacities were mainly rounded, but their localization in the base of the lungs was not typical of silicosis.

Since all of the films of the known silicotics were classified as pathological, the sensitivity of the ILO classification was good. There was good agreement among the readers in their classification of the films from the concrete workers. In only 8 of 271 cases did the readings differ more than one stage on the ILO scale.

One hundred and twenty-six workers did not participate in the telephone interview, and radiographic readings were not made for 58 who fulfilled the inclusion criteria for exposure at the time of the interview. Many of these 184 individuals did not live in the Stockholm area, which was another of our inclusion criteria. The medical records including earlier radiographic reports were reviewed for these 184 persons, and nothing indicating suspicion of pneumoconiosis was found in any of the records. Furthermore, none of these men could be found in the Swedish national register of patients with silicosis.

The risk for recall bias concerning exposure must of course be taken into account in all retrospective studies, since time with high exposure is often overestimated. Furthermore the exposure estimates for different work tasks were crude, and our exposure calculations can only be considered to give an indication of the level of exposure. There may be alternative explanations for the four films with ILO classifications of $1 / 0$ or $1 / 1$. The readings are somewhat dependent on how the investigation is carried out, and, for example, a less than maximal deep breath at the time of exposure can produce films that are classified as $1 / 1$ despite the absence of lung parenchymal changes. In three of the four cases with profusion $1 / 0$ or $1 / 1$ the clinical radiologist, who also used side and oblique projections, had noted thickened extrapleural tissues. It is possible that shadows from these were interpreted as small opacities in the ILO classification. All four
Table 2. Occurrence of small opacities in the 271 concrete workers according to the classification of the International Labour Organization (ILO).

\begin{tabular}{lrlllllll}
\hline \multirow{2}{*}{$\begin{array}{l}\text { LOO } \\
\text { category }\end{array}$} & $\mathrm{N}$ & \multicolumn{6}{c}{ Shape and size } \\
\cline { 3 - 8 } & & $\mathrm{pp}$ & $\mathrm{ps}$ & $\mathrm{pt}$ & $\mathrm{qt}$ & st & $\mathrm{qt}$ \\
\hline $0 / 0$ & 249 & - & - & - & - & - & - \\
$0 / 1$ & 18 & & 1 & 3 & 1 & 2 & 9 & 2 \\
$1 / 0$ & 3 & & 1 & - & - & 1 & 1 & - \\
$1 / 1$ & 1 & - & - & - & - & 1 & - \\
\hline
\end{tabular}

a Profusion category according to standard radiographs (10).

b The shape of small opacities is recorded as round ( $p, q, r)$ or irregular $(s, t, u)$. The size is presented as diameter/width $<1.5 \mathrm{~mm}(\mathrm{p}, \mathrm{s}), 1.5-3 \mathrm{~mm}(\mathrm{q}, \mathrm{t})$ and $>3 \mathrm{~mm}(\mathrm{r}, \mathrm{u})$. The predominant shape/size is recorded as the first letter. The symbol is given twice if virtually all of the opacities are of the same shape and size. If another shapelsize is seen, it is recorded as the second letter (10).

Table 3. Association between smoking habits and the occurrence of small opacities according to the classification of the International Labour Organization (ILO).

\begin{tabular}{|c|c|c|c|c|c|c|}
\hline \multirow{2}{*}{$\begin{array}{l}\text { ILO } \\
\text { categorya }\end{array}$} & \multicolumn{2}{|c|}{$\begin{array}{l}\text { Nonsmokers } \\
\quad(N=52)\end{array}$} & \multicolumn{2}{|c|}{$\begin{array}{l}\text { Ex-smokers } \\
(\mathrm{N}=126)\end{array}$} & \multicolumn{2}{|c|}{$\begin{array}{l}\text { Smokers } \\
(N=93)\end{array}$} \\
\hline & $\mathrm{N}$ & $\%$ & $\mathbf{N}$ & $\%$ & $\mathbf{N}$ & $\%$ \\
\hline $0 / 0$ & 50 & 96.2 & 114 & 90.5 & 85 & 91.4 \\
\hline $0 / 1$ & 2 & 3.8 & 9 & 7.1 & 7 & 7.5 \\
\hline $1 / 0$ & - & - & 2 & 1.6 & 1 & 1.1 \\
\hline $1 / 1$ & - & - & 1 & 0.8 & - & - \\
\hline
\end{tabular}

a Profusion category according to standard radiographs (10).

of the concrete workers with small opacities classified as $1 / 0$ or $1 / 1$ were smokers, and an increased frequency of smokers was also observed among those with $0 / 1$ profusion. It has been reported that small opacities up to profusion $1 / 1$ are more common among smokers and are also related to interstitial fibrosis caused by smoking (11). However, other authors have failed to demonstrate an association between smoking and small opacities in populations not occupationally exposed to dust or in silica-exposed populations (12). Asbestos exposure cannot fully be ruled out as an explanation for the small opacities since asbestos has been very common in the Swedish construction industry in the past. In an earlier investigation of Swedish construction workers $11 \%$ had pleural plaques (13), and an investigation with thoracoscopy showed that $67 \%$ of construction workers have pleural plaques when more than 30 years have elapsed since their first employment (14). In this investigation $24 \%$ of the individuals had pleural plaques or diffuse pleural thickening. The different prevalence of pleural changes between this and the earlier Swedish investigation is probably due to the fact that Askergren \& Szamosi (13) used diagnostic criteria other than the ILO classification.

This investigation shows that the risk of contracting silicosis from work with concrete in Sweden in recent decades has been small. In the literature a few more than ten cases have been reported in which concrete 
work was judged to have caused silicosis. These cases usually concern workers with specialized tasks involving high dust exposure (eg, mixing concrete in special circumstances, breaking, drilling, and dry grinding). The work in these cases has often been carried out in closed and poorly ventilated locations. Thus chest radiographic screening only seems justified for those who have had specialized tasks involving greater and more prolonged silica dust exposure than concrete workers in general.

\section{Acknowledgments}

We are grateful to Dr B Salomon, who participated in the ILO reading, Dr A Szamosi, who performed the clinical radiographic readings, Ms E Stålfors, who interviewed the concrete workers, and Dr B Evanoff for his linguistic assistance. The study was financed by grants from the National Board of Occupational Safety and Bygghälsan.

\section{References}

1. National Institute for Occupational Safety and Health. Criteria for a recommended standard: occupational exposure to crystalline silica. Washington, DC: Government Printing Office, 1974.

2. American Conference of Governmental Industrial Hygienists (ACGIH). Documentation of the threshold limit values for substances in workroom air. Cincinnati, OH: ACGIH, 1971.

3. Ahlmark A, Bruce T, Nyström Å. Silicosis and other pneumoconiosis in Sweden. Stockholm: Scandinavian
University Books, 1960.

4. Bernadou J-M, Fréour P, Monmayou R, Cloteau J-P. La Silicose dans les professions du béton. Arch Mal Prof Méd Trav Sécur Soc 1970;31:617-24.

5. Hodel T, Schlegel H, Rüttner JR. Backstein- und Betonbohrersilicose. Schweiz Med Wochenschr 1977;107: 1986-99.

6. Marchand M-C. Contribution à l'étude de la Silicose [dissertation]. Paris: Université de Paris VI, Faculté de médicine Broussais - Hôtel-Dieu, 1977.

7. Sors G-B, Cabasson Y, Delplace Y, Tufel Cl, Cavigneauz A. Silicose pulmonaire chez des ouvriers du bâtiment et des travaux publics. Arch Mal Prof Méd Trav Sécur Soc 1972;33:301-5.

8. Stetter K. Beitrag zur Frage der Staublungenerkrankungen. Beitr Klin Tuberk 1930;76:724-37.

9. Askergren A, Tollqvist J. Förekomst av silikos i "otraditionella yrken" [Incidence of silicosis in "untraditional occupations"]. Läkartidningen 1970;77:4781-3.

10. International Labour Office (ILO). Guidelines for the use of ILO international classification of radiographs of pneumoconiosis. Revised edition. Geneva: ILO, 1980.

11. Weiss W. Smoking and pulmonary fibrosis. J Occup Med 1988;30:33-9.

12. Blanc PD, Gamsu G. The effect of cigarette smoking on the detection of small radiographic opacities in inorganic dust disease. J Thorac Imag 1988;3:51-6.

13. Askergren A, Szamosi A. Relation between radiological pleuropulmonary changes, clinical history and weight index of construction workers. Scand J Work Environ Health 1978;4:179-83.

14. Stjernberg N. Förekomst och betydelse av pleuraplaques hos asbestexponerade byggnadsarbetare [Incidence and significance of pleural plaques among asbestos exposed construction workers]. Stockholm: Bygghälsans forskningsstiftelse, 1977. (Report 1977:6.)

Received for publication: 15 April 1991 